\title{
Race and Desire: \\ Toward Critical Literacies for ESL
}

Ardiss Mackie

This article examines the complexities of race and teaching identity and their coupling with desire. The author contributes to a theory of critical literacies for ESL by questioning the construction of whiteness as it relates to ESL. She draws on a cross-disciplinary bibliography of critical pedagogy, cultural, and feminist studies. She suggests that an interesting paradox in critical literacy is the simultaneous breaking down of binary identities while continuing to offer up a socially transformative curriculum.

La complexité des questions de race et de l'enseignement de l'identité dans le contexte du désir, constitue le thème de cet article. L'auteur remet en question la construction de la "blancheur » dans le contexte de l'ALS, contribuant ainsi à la théorie des littéracies critiques en ALS. L'auteure puise dans une bibliographie pluridisciplinaire touchant la pédagogie critique, les études culturelles et les études de la condition féminine. Elle révèle un paradoxe intéressant dans l'écroulement des identités binaires qui se produit dans le contexte de programmes d'études visant une transformation sociale.

There is a near avoidance of race in theories of language teaching and learning and in researchers and teachers challenging their raced assumptions in theory building. It is uncomfortable work (Kubota, 2002). The point, however, is not simply to admit one's racism, but to identify its formations and connections to wider discursive practices and communities in order to see color, recognizing that white too is a color. The aim of this article is to question whiteness in ESL teaching by situating it in a theoretical framework that draws as much on theoretical positions as on critical incidents in learning whiteness.

\section{Position and Organization}

Social categories of identity such as race, gender, sexuality, and nationality have been introduced to TESL discourse in the last several years (Amin, 1997; Brutt-Griffler \& Samimy, 1999; Duff \& Uchida, 1997; Nelson, 1993; Norton, 1997; Schenke, 1991). Regarding race, Amin (2001) argues that minority immigrant ESL teachers in Canada, mainly women, are Otherized, considered to be non-native English speakers and less qualified than Canadian-born to teach ESL, privileging white native-speaking teachers. Maintaining that 
there is no privilege in white teachers receiving part-time pay for full-time work, Butler (2001) replies that the problem is not with the non-whiteness of teachers, but with the third-world status that ESL occupies in North American institutions. To the dichotomy of the debate on race and ESL teaching identity, I add a third space, a borderland between the constructions of ESL teachers as non-native or native and non-white or white.

I argue that by questioning racial identity, various positions, including the colonized identities of ESL teaching, are dislodged. Drawing out the complexities that bind race with desire is a pathway both to redrawing the border and to critical literacies. Critical literacies include reflecting on how personal and social desires are shaped by our engagement with everyday cultural texts (Kelly, 1997). Critical literacies both in teacher education and ESL teaching read cultural (pedagogic) texts for their unstated purposes and interests. (See Pennycook, 1996, for further discussion on the diverse meanings of critical literacies.)

Fusing narrative with other forms of scholarly writing, this article connects critical incidents from my past to theoretical positions on identity. In choosing to write in a style uncommon in scholarly journals in ESL, I stand alongside Canagarajah (1996) who calls for alternate writing forms to the scientific-empirical report with its introduction, method, results, and discussion. Writing forms that weave theoretical with personal threads relieve the theory-practice dichotomy. Accordingly, I connect personal history with theoretical positions and ask: What critical incidents hold meaning for the construction of whiteness and desire? How might this history intersect with ESL teaching identity? How might it be located in practices that question the postcolonial discourses of ESL?

Because my early experience in learning race was shaped by a film, the following two sections examine work on teaching identities and popular film. I draw on early experiences of race and desire while growing up in Whitehorse, Yukon. The third section sifts through ESL teaching experiences in various settings to illustrate the shifting meanings of whiteness and desire. Here I look at the colonization of ESL identities, including liberal multicultural discourse on identity and race. In the fourth section I discuss the possibility of third-space positions in critical practice.

\section{Teaching Identity and Popular Film}

Several educators have established film as a powerful source of identity formation for teachers. In examining the responses of 12 female preservice primary teachers to the film Stand and Deliver (Menendez, 1988), Robertson (1997) questions the role of gender in the teachers' fantasy of devotion to teaching and the respect of Othered students. She locates this fantasy in a Western historical context where teacher training has traditionally positioned female teachers as missionaries and crusaders. Viewing Stand and 
Deliver through a different lens, Biklen (1995) argues that the film critiques schooling in relation to race by identifying the nonheroic teachers as racist and prejudiced because they have low expectations of less privileged students. The film constructs the heroic teacher as a man who works alone against the administration and the other racist teachers. Bilken maintains that there are both advantages and disadvantages to the film teacher as hero. Heroic teachers legitimize the lives of students, resist the conventional, and use best practices. However, portraits of heroism are also gendered, so that the heroic life of the male takes over while someone else tends the family. In addition, film heroes are often conservative and not always revolutionary resisters.

In examining two films, Exotica (1994) and To Sir With Love (Clavell, 1967), Kelly (1997) is concerned with how popular texts might form the basis for questions about education and subjectivity. As such, she asks questions about the gaze, knowing, and difference, and about the embodied cinematic subjects of the films in terms of their race, gender, sexuality, and class. With To Sir With Love she explores her responses to the film when she was a teenager. As a white schoolgirl viewing the movie, Kelly identified not with any of the white female students but with the black teacher. Kelly believes it is in these hybrid identifications that the cinema holds such extraordinary power: by presenting viewers with possibilities of who they could be and of the communities they could enter. Her interest is in questioning how culture informs desire and the constitution of pleasurable teaching. Indeed, she traces her own eros in teaching to the film and its title song by Lulu.

Another interesting example of the indelible influence of film on emerging identities and ESL learning is given by Said (1999). Said attended Englishmedium schools while growing up in Egypt. During this time, he watched Hollywood movies "portraying" the Middle East. Said claims that,

It did not occur to me that the cinematic Aladdin, Ali Baba, and Sinbad, whose genies, Baghdad cronies, and sultans I completely possessed in the fantasies I counterpointed with my [English] lessons, all had American accents, spoke no Arabic, and ate mysterious foods-perhaps "sweetmeats," or was it more like stew, rice, lamb cutlets?- that I could never quite make out. (p. 34)

In discussing Tarzan movies, he addresses the strength of the movie viewing experience in invoking desire in images of womanliness and manliness as well as in identification of his "real" life in metropolitan Egypt with that of the screen images of jungle life. He makes the point that it is in a Western Hollywood image of non-Western people that his fantasies of Middle Eastern countries emerged without question.

Finally, Vandrick (1999) questions the influence of popular cinematic representations of colonial privilege on ESL teaching identity. Films such as 
The Jewel in the Crown (Moraham, \& O'Brien, 1984) represent the colonizers' experience as romantic but they also obscure the darker side of racism and exploitation of Indigenous people. She connects her life as the child of missionary parents in India to an (unconscious) "ministering to the natives" attitude toward ESL students.

When the lights go out and the spectator enters the liminal world of semi-darkness and great images, sounds, and stories, the power of the cinematic experience can be so compelling that even representations of ourselves and our communities, however false, become visions of the desirable. As I questioned how I learned to be white, a film repeatedly came to mind. Like Kelly (1997) and Said (1999), I invoke the memory of the film and the meanings that it held for me at the age of 7 and the meanings I make for it now as a white female teacher.

\section{To Kill a Mockingbird: Coupling Race with Desire}

I was spellbound in my theater seat watching To Kill a Mockingbird (Mulligan, 1962) and identified completely with Scout, a girl of my own age, gender, race, and pixie haircut, who narrates the story from an older age. Scout's single-father lawyer Atticus, played by Gregory Peck, unsuccessfully defends a Black man, Tom, accused of raping Mayella, a poor white woman. Despite Atticus presenting evidence that Tom could not possibly have raped Mayella, Tom is found guilty, and he is murdered as he leaves the town for his imprisonment. The story unfolds in Alabama in the 1930s, mainly over the summer holidays, and Scout and her slightly older brother Jem watch the trial, play outdoors, taunting and later befriending their reclusive neighbor Boo. The story encompasses two narratives: that of the trial and that of the relationship with Boo. The central questions in the story are about race, gender, and difference and all through the eyes of a girl my age who looked like me.

Several interesting threads from this movie contributed to my associations of gender, race, and class and entwined these with various forms of desire. I admired Atticus. Not only was he a patient father, he was also firmly against the racial prejudice of the community. For me he became "the great white father," appearing to be more generous and noble than the poor white men, while the Black man Tom depends on him for his freedom. It seemed obvious that Atticus was right and that the racism the poor white community demonstrated was wrong. I was against the poor white community mainly because of Mayella's father's lying about the events and Tom's murder. At the same time, I felt sorry for Mayella because she was obviously being controlled by a mean father who beat her and then made her blame and publicly accuse Tom, a man to whom she was secretly attracted. Tom is indeed big, strong, and polite. Tom testifies that Mayella embraced him; Mayella testifies that she asked him to stop and help her with some chores. I 
was in awe of the trial where Mayella is made to tell in court her story of being raped by Tom.

The secret and shameful desire of a white woman for a dark man is transformed into a rape fantasy, which is then made public by white men through an intensely emotional trial behind which the community has rallied. To Kill a Mockingbird was released in 1962, when white supremacy in the United States was threatened by the Black Liberation movement. The story of Mayella's rape by a Black man stands in for the threat confronting the white community. The film juxtaposes various forms of desire and in so doing sets up raced, classed, and gendered divisions: the desire for racial justice against the desire to oppress Black people; Mayella's desire for Tom against her father's desire to control her; Tom's desire to be a "Southern gentleman" and help Mayella against Atticus's desire to help Tom.

That this film has remained in my memory and was recalled repeatedly as I questioned the learning of whiteness speaks to the power that film has as a form of pedagogy, one from which we learn something, and one to which even the most critical viewers give themselves over, at least momentarily (hooks, 1996). I trace my own white longing to empower oppressed people with this film. Certain colonial tropes also spring from this early cinematic experience and underpin this desire. These include, first, the class- and gender-based trope of moral superiority constructed through the lawyer as "great white father," a defender of Black equality using eloquent and articulate speech, patient in teaching his children various moral lessons, yet strong enough to take a gun and kill a rabid dog. This image of the middle-class, white, respectable father is juxtaposed with Mayella's father, a man from the lower classes, an unemployed drinker whose incestuous relationship with his daughter is hinted at, whose physical abuse of her is portrayed, a man who shows disrespect and curses.

Second is the trope of interracial desire as dangerous. Mayella's responsibility as the oldest child is to look after the younger children while her father neglects her except through abusive acts. Tom, as someone who often passes by her home, is familiar and desirable. Tom sees she needs help, indeed feels sorry for her even though she is white, and wants to help her. Yet these responses to each other result in shame or death.

The context in which I viewed this movie is also influential in the effect of the film on my developing sense of race. I saw the movie in a small city in the Yukon Territory of Canada. I was born and raised in northern Canada, and my racial privilege developed in opposition to the unprivileged position of First Nations people. Later in the same year, as I watched To Kill a Mockingbird, I had a second lesson in race. My older brother's bicycle had been stolen, but he knew where it was, so my father drove him there, and I went along for the ride. This was the first time I saw a First Nations community, as their housing was always separated from white housing in the four northern 
communities we lived in. My dad, brother, and I drove through Indian Flats, the flat part of Whitehorse beside the river. Like the Black residents in To Kill a Mockingbird, many First Nations people lived separately from the white community. The houses were mostly small, unheated, with broken windows, open doors, and the roads were unpaved and potholed. The bike lay in front of the open door of one house. A dark boy my brother's size stood and watched from the doorway as my dad put the bike in the trunk. No words were exchanged.

Both the film and the contact with a First Nations community were critical incidents in my constructing race. They associated in my mind "Indianness" with Otherness through poverty, theft, and voicelessness in the case of the First Nations people, and sexual attraction, wrongful treatment, death, and the failure of the white man to rescue or provide safety in the case of men of color. I did not learn to hate First Nations people, but to feel sorry for them. I did not learn to hate people of color from the movie, but to associate them with victimization, helplessness, and sexuality. These early critical incidents began to entwine race with desire. They associated in my mind the dark/other with poverty and racial inequality and injustice, and white wealth with privilege, sexual desire, and the desire to correct wrong. The racialized Other became attractive, poor, and at the mercy of white privilege, yet still able to offer and take. My white female identity mixed a sympathy for the dark/other with a desire to help him while being attracted by and to him. A decade later, another powerful movie called Billy Jack (Laughlin, 1971) strengthened these threads among desire, race, and gender.

A challenging practice of critical literacies is the examination of the structures of power in the classroom, and this entails questioning how our racial identities are shaped by cultural texts. I identify specific incidents as factors in coupling my sense of longing with being white. Yet these threads of racial identity connect to a larger historical fabric of colonization. It is to colonial and postcolonial discourse and their influences on ESL that I turn below.

\section{Colonial and Postcolonial Discourse and ESL Identity}

That teaching English to colonized people was a major part of the desire to civilize is clearly traced by Pennycook (1998). The rationale for educating in English, however, was articulated differently in colonized nations. In Canada it was believed that complete assimilation of culture and language was the only way to "civilize" First Nations people (Grant, 1983). It was also generally understood that the younger the children were, the easier assimilation would be. This was the underlying reason for residential schools in Canada where the tragic consequences of forced assimilation to English continue to be heard (Grant, 1996). English teachers were part of what Said (1994) calls "the experts in ideas" (p. 131), the imperial crew made up of 
missionaries, teachers, advisers, government agents, and scholars who were implicated in "westernizing the backward" (p. 131). English was interpellated as the language of power and superiority, whereas First Nations languages became Other and extinct, so that not only was a hierarchy of languages established by colonial order and "expertise," but also human bodies according to various racial characteristics.

The assignment of desire to race and nation or geographical location still holds true today in popular discourses as well as ESL discourse (see Susser, 1998, for a discussion of orientalist discourse in English teaching in Japan). "The French" have something inherently sexy about them, and "Latin Lovers" are "hotter" than their northern, lighter counterparts. Asian males are divested of desire in mainstream white popular culture while Asian women are imaged as objects of white male desire (Luke, 1998). Desire is not in the body, but rather has a relation to the body, and this relation can be located in various discourses. Tracing the lines in such discourses leads us to re-identifications, re-markings of earlier borderlines of who we are and what we can do. Desire as a social construct offers an unbinding of the naturalized and colonized discourses of desire and social categories of race, gender, nation, class, and so forth.

In my case the desire to be a liberator-teacher was at its highest point during my BEd program. From this formal TESL education, I learned the technical aspects of learning and teaching ESL, and these classes have served me well. But at the same time my roommates introduced me to alternatives in language teaching theories-Freire (1983), Shor (1980), Kozol (1980)-that connected literacy to wider social frameworks and viewed teaching as a political act. Every chance I had when doing assignments I wrote about the success of Freire's many literacy campaigns in Central and South America. Naturally, the famous red and black poster of Che Guevara wearing his beret hung on my bedroom wall. I wanted to travel there, and when I learned that Grenada, an English-speaking country, also had a Freirian-based literacy campaign, I imagined myself teaching Grenadian peasants. I acquired the books that were used in Grenada. They had sentences like "The revolution provides milk for mothers and babies" and blank lines for the students to copy. My desire to help illiterate people was again entwined with romantic desire in the figure of the handsome and tragic Che.

I was brought swiftly back to reality when I met with the professor for whom I had written the Grenadian paper and included the literacy materials to discuss the undeserving (I thought) B grade he had given me. Instead, he warned me: "You'd better watch out, young lady, or before you know it, you'll be carrying a machine gun on your back in a Central American jungle." His image of the danger I might come across was not far from the liberating and romantic image I desired for myself, but the pen was my 
weapon! I politely thanked him for his warning. He did not change my grade.

My initial interest in teaching ESL stemmed from an attraction to racial Others and my desire to help them overcome oppressive circumstances. The "ESL Other" was, then, for me a monolithic community of people, joined by their sameness to each other and their difference from me, and by their dependence on me to help them out of their difficulties and to provide a model of Canadianness to which they could aspire. This early teaching identity, based in various desires, seems so much a part of the colonial discourse of ESL teaching, complete with an exotification of the racial Other, a missionary zeal to teach and develop curriculum that would prove "helpful" to refugees and immigrants entering white culture (Vandrick, 1999), and the unquestioned privilege of white womanhood to travel the world and teach a language whose position in the world seemed unquestioned.

Two years after completing the BEd, I was in northern China teaching EFL to English teachers, translators, engineers, and architects. The students had been hand-picked to study English, privileged among their colleagues, not at all the oppressed and illiterate peasants of Paulo Freire's programs. Thus began the unraveling of the "oppressed student" identity. Discourses that identified students as oppressed were disjointed from my day-to-day experience in China. Like Schenke (1991), I could not commit myself to this colonial division.

As an ESL teacher moving from Canada to China and later from Canada to Japan, my sense of myself as a woman also shifted to that of a white woman through various experiences. That my body is raced, marked by physical features recognizably different from others, and that these features hold meaning apart from the physical, became knowledge to me only when $I$ left Canada as an adult. It was then that my whiteness and the privileges attached to it in Canada became conscious. Until then race was for "other" people. Whiteness was the ordinary, the unmarked and unquestioned standard body, and therefore held a universality that in turn marked nonwhiteness as different, as Other. This is not to say that I was unaware of race. As I relate above, I realized that there were bodies and communities different from mine.

In China, my body as white female was the visible minority Other: the students wished to spend much time with me because I was their linguistic, cultural Other and in the community; I was recognized as the racial Other. In a site where few white people had been seen, I was a "da bi" (big nose), someone with freckly skin, brown hair, and weird clothes. When I spoke Chinese to postal or store clerks, they often did not respond, perhaps not recognizing in my racial features the ability to speak, albeit limited, Chinese. The stares, jeers, pointed fingers, nudges to the looker's companion all gave me a sense of alienation, of being an alien. I felt the gaze, but not the white 
male gaze of being assessed, objectified, dismissed, or appreciated for female difference. This gaze was more complex, but still body-related. Now the difference included facial features, hair color, body shape and size, and skin color. Here I was Otherized, but being the Other I was also thought to have knowledge about all manner of things, including dancing, music, world history, classic English literature, movie stars, sports rules and heroes, and so on. Second, it was seen as my job as an English teacher to impart this knowledge, either in class or elsewhere. The identity that colonizers built for themselves as more knowledgeable and worldly has a postcolonial residue for native English-speaking teachers who are sometimes seen by students, bosses, and themselves as all-knowing. Being Other here was a contradictory position, sometimes valued for "whiteness = knowledge" and sometimes devalued as "whiteness = unable to communicate, ugly."

Living in Japan for three years in the 1990s, I again understood that my different body produced particular responses in Japanese people from start to longing, and again from discrimination-as-derision to discrimination-asprivilege. A freckly face and body marked inferior skin, "an advanced European form of leprosy" (Alexander, 1993, p. 116), a high nose the object of scrutiny and astonishment, and brown hair, a popular hair dye choice in Japan at the time, received desirous and admiring looks.

Ahmed's (1997) term migratory is helpful in looking at identity and racial difference. By migratory, she means something other than the physical sense of leaving a country or place and moving to another. Rather, migration is that shift in identity that takes place over time and situation, a migration of identity that can be violent. When I was waiting for the elevator by myself at the university where I taught, the door opened and an older Japanese male professor's reaction of shock at seeing me, a white female lecturer, violently disrupted who I was. His body bolted backward, his mouth dropped open, his voice gasped. Did I cause this? There was no one else present. His gaze was on me. What was it about me that caused it? Somehow I was a frightening Other. I am freckled/not clear skinned, I have a tall nose/not a flat one, I have a long face/not a round one, I have brown hair/not black. I was the unexpected different one. I was wearing the appropriate attire, I gave the professor a head bow, my hair was neat, I was contained. But knowing the correct address was not enough to counter the fact of my whiteness, my alienness.

I tried to fit in by acting how I thought a Japanese woman would be expected to behave. I practiced a kind of silence. Instead of striking up conversations, I nodded my head in recognition. On those occasions when talk was called for, I said little, believing that this silence was what Japanese women did, and although I was not Japanese, I was a woman and I wanted to be part of a community. To hide my racial features when I went for a walk or bike ride, I often camouflaged my body by wearing hats, sunglasses, and 
baggy clothes. At the public bath one evening, I saw a woman shaving her face. I asked my Japanese language tutor about it, a common practice, and she gave me detailed instructions. I went shopping for a facial razor for women, but when I talked to my husband about it, he was horrified that I would ever consider doing it (probably worried that I would grow a beard!).

My attempts to perform like a Japanese woman resulted more in frustration than anything. When I was riding my bicycle home from work one day at dusk, a motor scooter hit me and I was thrown off my bike. The motorist slowed down as he passed me and asked if I was okay. I answered that I was as I dragged my bike and myself to the curb. In fact I was injured, although not seriously. I thought my reaction was Japanese-woman-like until I mentioned it to two Japanese female colleagues who said that they would have cried out, definitely not said that they were all right, got the motorist's license number, and other actions I never thought a Japanese woman would take. I had been basing my attempts on a faulty premise, that is, that there is "the Japanese woman," that she is silent, passive, demure. Whether ridiculed or admired, my race, not me, came before anything else about me. My raced position was not something I could ignore. Being a white woman in Japan meant I was not on the inside. But I am not claiming racial oppression as my story here. I am suggesting that identity categories are sometimes false constructions ("the Japanese woman," "the oppressed student," "the white teacher") and that location or situation is a crucial part of how we see and how we are seen.

In Japan an entire English-language industry fosters a desirous world of wealth, travel, romance, work, beauty, and knowledge where white foreigners are sought out for their image. Glossy ESL textbooks picture white teachers and students having fun around the world. A fun and adventurous curriculum sells. On city buses, an advertisement for a popular English-language school showed a young blond white man bent over a young pretty Japanese woman, her eye on him, his eye on the book. A romantic curriculum sells. Again we have a discourse that couples teaching-learning relationships with power and desire. Reading such discourse critically means questioning the possibilities for language-learning and teaching that these representations hold. These possibilities sometimes do become our experience. Many of my students did travel outside Japan and came back with photos and souvenirs and fun memories, having used English to get around. And romance in foreign countries can be exciting. It is not that such advertising is false or wrong. (I am not identifying myself as "white-womanas-prude.") Rather, it is the truth values and limitations that adhere to such discourses, to the subject that we teach, to the experiences and identities we should have, that can be exclusionary and unproblematized. Questions emerge about the globalization of English and the role that white ESL teachers around the world play in sustaining that globalization. 
Now back in Canada, I am also wary of liberal discourses on multicultural identity and ESL. That issues of race have been addressed through liberal multicultural policies in Canada is a position that needs scrutiny. Although whiteness and race theories emerge, practical experiences in educational settings evidence a need for more race-consciousness in the white population. $\mathrm{Ng}$ (1993) relates an experience of racism and sexism in teaching a university course. She draws attention to the difficulties that visibleminority female teachers can face. Dunlop (1999) similarly discusses the challenges of working in academia and the limitations of hyphenated identities such as Indo-Canadian.

I draw on a recent example to illustrate how identity is (mis)constructed in everyday educational discourse. At the end of the winter term in 2001, the following letter written by "Concerned Student" was left for some ESL teachers where I work.

Dear English Second Language Instructor,

Can you explain why most Asian male and female students at [] are cold and distant towards Caucasian students? For example, they tend to congregate amongst themselves and they don't say hello or communicate in any way to other [] students. Also, they tend to show anti-social behavior towards [] students such as looking the other way when passing by a student and they don't make eye contact and smile at other [] students. I was wondering if you would tell them to start acting like the ambassadors from their respective countries and treat [] students with some courtesy and respect. You may find it hard to believe but there are some [] students who want to talk to Asian students and develop different types of relationships with them. Thank you for spending the time and reading this letter.

The letter is disturbing from several viewpoints, but I focus on the issues of identity and race. The underlying assumptions are: Caucasian students are the standard; Asians in the institution are ESL students; Asians are non- or substandard ("cold," "distant," "don't say hello," "anti-social," "don't make eye-contact," etc.); Asians should act like Caucasians and not vice versa. Indeed, the condition for "other relationships" with the writer is ESL students behaving like "Caucasians." The writer constructs his or her Caucasian identity in a position of power relative to Asian students. The writer is unaware that the region has many long-standing Chinese and Japanese families and that First Nations people make up a substantial proportion of the population. The writer may be mistaking these students for ESL students. There are also students from Iran, India, Haiti, and Mexico to name a few. She or he is also unaware that the examples of "anti-social behavior" for "Caucasians" are considered polite behavior for Other people. That the letter was delivered to ESL teachers, not the "offending" students themselves is 
indicative of the continued postcolonial identification of ESL teachers as "saviours" and "correctors" and of ESL students as "barbaric" and "misbehaving" students. My point is not to single out a particular student or workplace as racist, but rather to question the public discourse on race, internationalism, and multiculturalism. It continues to be loaded with postcolonial subjects: us (Caucasian, standard, dominant) and them (Asian, nonstandard, nondominant), with a subverted desire to "develop different types of relationships with [Asian students]."

\section{Third Space Positioning: Borderlands of Common Interests}

Third space refers to shifts in knowledge and knowledge representation (Gutierrez, Baquedano-Lopez, \& Turner, 1997). Unscripted dialogues (scripts that are uncharacteristic of teachers and students) constitute third space, and the interests of teachers and students are made available to each other (Gutierrez, Rhymes, \& Larson, 1995). I extend the notion of third space to collegial scripts in order to illustrate how binary categories of identity break down.

One year at the Japanese university, three Japanese male colleagues and I were invited to work on the entrance exam editing committee. Our job was to locate and correct errors and problems in the newly created tests. As the only native English-speaking member, I vetted each possible error. I was sought out for my mother tongue. I enjoyed the privilege of being valued.

The most valuable experience from this committee, however, was a friendship between one of the other members and myself. We were opposite in many ways. He was Japanese, tenured, and older. Nevertheless, we got to know a little about each other through the weeks spent on the committee work, and later he extended kindness to me outside of the university culture. Knowing that I was a feminist, he invited my husband and me to cultural events such as film debuts. The films were about the struggles of women and minorities in Japan. He also introduced me to the Kyoto City Women's Center whose library had many feminist works in English and thus came to be a significant source for my research. He was a man deeply committed to social causes, involved in the performing arts, and enjoyed reading English literature. I admired him, and appreciated his hand of friendship.

He retired while I was still teaching there, and so I sent him a retirement card with a poem I had written in Kyoto, "November Sun":

The laundry hangs on bamboo poles, the geranium languishes in November sun, and I, comforted by the glow

now full upon us all sleep on a grass mat

knowing green leaves are turning

as they should

to red. 
He responded with a touching letter of thanks. He liked the poem, but thought it should have the word not after are, to read "green leaves are not turning as they should to red." The poem had brought up something deeply personal for him. He told me that he still missed his beloved wife who had been taken by cancer. He wondered how I had known his wife had died. I had not known. The poem was written from another place, and I had given it to him because I imagined a sense of comfort in retirement. Of all the words he had received for his retirement, mine, he said, were the only valuable ones.

In this friendship, desire, shaped long ago as a white woman helping less privileged Others while being attracted by them, radically shifted. The friendship crossed so many boundaries of nationality, race, gender, age, and status and was supported by common interests in social conditions, language, and culture that "helping the less privileged" was again an unworkable script. The friendship enabled me to learn about various struggles of Japanese minorities. More important, however, he acted outside the script of my cultural expectations of Japanese men, and in turn the stereotyped image I had of Japanese males was disrupted. We simply had things in common, and they, not our differences, became our meeting space.

\section{Coda}

In relating the early construction of desire and whiteness to colonial history and postcolonial discourses, I support the notion of ESL identities as complexly formed by diverse influences and through critical moments in time and situational space. I show how such spaces might be occupied in ESL teaching and how they may be further shifted. Like identity, desire changes when we question its beginnings and its response to cultural texts.

The interesting question of doing critical work now is the obvious contradiction running through this article. That is, at the same time as the identities of "teacher = transformer/student = needing transformation" break down, critical literacies claim a larger social gaze than humanist literacy (individuality and creativity) or technical literacy (language-as-tool for business, etc). Teaching that works through the paradox of such competing discourses is the practice of critical literacy. Let us be wary, though, of simply taking center stage through identifying white privilege (Sheets, 2000) or sharing victimization with students (Rosenberg, 1997).

Rather, as McIntyre (1997) suggests, we expose whiteness to critique. Being color blind in the classroom where different colors are present neglects the possibility of learning who we are, how we got to the front of the classroom, and how re-markings and new positions can be built. For a curriculum that supports critical literacies, this means including, like Robertson (1997) and Kelly (1997), popular films and other everyday texts that are read not for mere personal growth, "edutainment," or a tool for 
language learning, but rather to undermine the opposing identities that adhere therein.

\section{Acknowledgments}

For their insightful and practical comments on earlier versions of this article, the author would like to thank Bonny Norton, John Willinsky, and three anonymous reviewers.

\section{The Author}

Ardiss Mackie is a doctoral candidate at the University of British Columbia. She has written articles in TESOL Quarterly and Pedagogy, Culture and Society. Her poetry has appeared in Contemporary Verse 2 and English Quarterly. She teaches at Okanagan University-College.

\section{References}

Ahmed, S. (1997). "It's a sun-tan, isn't it?" Autobiography as an identificatory practice. In H.S. Mirza (Ed.), Black British feminism: A reader (pp. 153-167). London: Routledge.

Alexander, M. (1993). Fault lines. New York: Feminist Press at the City University of New York.

Amin, N. (1997). Race and the identity of the nonnative ESL teacher. TESOL Quarterly, 31, 580-583.

Amin, N. (2001). Marginalization of non-white immigrant women ESL teachers in Canada. TESOL Matters, March-May.

Biklen, S. (1995). School work: Gender and the cultural construction of teaching. New York: Teachers College Press.

Brutt-Griffler, J., \& Samimy, K. (1999). Revisiting the colonial in the postcolonial: Critical praxis for nonnative-English-speaking teachers in a TESOL program. TESOL Quarterly, 33, 413-431.

Butler, D. (2001). Another view of non-white immigrant women ESL teachers in Canada. TESOL Matters, June-August.

Canagarajah, S. (1996). From critical research practice to critical research reporting. TESOL Quarterly, 30, 321-331.

Clavell, J. (Director). (1967). To Sir with love [Film].

Duff, P., \& Uchida, Y. (1997). The negotiation of teachers' sociocultural identities and practices in postsecondary EFL classrooms. TESOL Quarterly, 31, 451-486.

Dunlop, R. (1999). Beyond dualism: Toward a dialogic negotiation of difference. Canadian Journal of Education, 24(1), 57-69.

Egoyan, A. (Director). (1999). Exotica [Film].

Freire, P. (1983). Pedagogy of the oppressed. New York: Continuum.

Grant, S.D. (1983). Indian affairs under Duncan Campbell Scott: The Plains Cree of Saskatchewan 1913-1931. Journal of Canadian Studies, 18(3), 21-39.

Grant, A. (1996). No end of grief: Indian residential schools in Canada. Winnipeg, MN: Pemmican.

Gutierrez, K., Baquedano-Lopez, P., \& Turner, M. (1997). Putting language back into language arts: When the radical middle meets the third space. Language Arts, 74, 368-378.

Gutierrez, K., Rymes, B., \& Larson, J. (1995). Script, counterscript, and underlife in the classrooms: James Brown versus Brown v. Board of Education. Harvard Educational Review, $65,445-471$.

hooks, b. (1996). Reel to real: Sex, race, and class at the movies. New York: Routledge.

Kelly, U. (1997). Schooling desire: Literacy, cultural politics, and pedagogy. London and New York: Routledge.

Kozol, J. (1980). Prisoners of silence: Breaking the bonds of adult illiteracy in the United States. New York: Continuum.

Kubota, R. (2002). The author responds. Un(ravelling) racism in a nice field like TESOL. TESOL Quarterly, 36, 84-92. 
Laughlin, T. (1971). Billy Jack [Film].

Luke, A. (1998). Producing new Asian masculinities. In N. Bruce \& C. Barron (Eds.), Knowledge and discourse. London: Longman.

McIntyre, A. (1997). Making meaning of whiteness: Exploring racial identity with white teachers. New York: SUNY Press.

Menendez, R. (Director). (1988). Stand and deliver [Film].

Moraham, C., \& O'Brien, J. (Directors). (1984). The jewel in the crown [Film].

Mulligan, R. (Director). (1962). To kill a mockingbird. [Film].

Nelson, C. (1993). Heterosexism in ESL: Examining our attitudes. TESOL Quarterly, 27, 143-150.

$\mathrm{Ng}$, R. (1993). "A woman out of control": Deconstructing sexism and racism in the university. Canadian Journal of Education, 18, 189-205.

Norton, B. (1997). Language, identity, and the ownership of English. TESOL Quarterly, 31, 409-429.

Pennycook, A. (1996). TESOL and critical literacies: Modern, post, or neo? TESOL Quarterly, 30, 163-171.

Pennycook, A. (1998). English and the discourses of colonialism. London: Routledge.

Robertson, J. (1997). Fantasy's confines: Popular culture and the education of the female primary-school teacher. In S. Todd (Ed.), Learning desire: Perspectives on pedagogy, culture, and the unsaid. London and New York: Routledge.

Rosenberg, P. (1997). Underground discourses: Exploring whiteness in teacher education. In M. Fine (Ed.), Off white: Readings on race, power and society. New York: Routlędge.

Said. E. (1994). Culture and imperialism. New York: Vintage.

Said, E. (1999). Out of place. New York: Knopf.

Schenke, A. (1991). The "will to reciprocity" and the work of memory: Fictioning speaking out of silence in E.S.L. and feminist pedagogy. Resources for Feminist Research, 20(3/4), 47-55.

Sheets, R. (2000). Advancing the field or taking center stage: The white movement in multicultural education. Educational Researcher, 29(9), 15-21.

Shor, I. (1980). Critical teaching and everyday life. Chicago, IL: University of Chicago Press.

Susser, B. (1998). EFLAfs othering of Japan: Orientalism in English language teaching. JALT Journal, 20(1), 49-82.

Vandrick, S. (1999). Passages from India. American Language Review, 3(4), $27-29$. 